\title{
Impact of Total Quality Management on Operational Performance
}

\author{
B.T.D.N. Senarath ${ }^{1}$, G.C.I. Gunarathne ${ }^{2}$, T.S.S. \\ Fernando $^{3}$
}

\author{
Department of Operations Management ${ }^{1,2}$, Department of \\ Management Studies, Faculty of Management, University of \\ Peradeniya
}

\begin{abstract}
dinusenarath95@gmail.com ${ }^{1}$, isurugune.jp@gmail.com², fernandotss28@gmail.com ${ }^{3}$
\end{abstract}

Received: 06 August 2020

Accepted: 17 October 2020

\begin{abstract}
The study explores the impact of Total Quality Management (TQM) practices on operational performance using a sample of 279 in Sri Lankan large scaled manufacturing organizations. Two hypotheses were tested using structural equation modeling. The study showed that TQM practices have a positive impact on operational performance and all the six TQM indicators individually have positive impacts on operational performance. This study suggests that the large scaled manufacturing organizations in Sri Lanka will be able to increase the operational performance during their peak seasons by implementing TQM while facing the competitiveness in the market place.
\end{abstract}

Keywords: Total Quality Management, Operational Performance, Structural Equation Modeling, Large Scaled Manufacturing Organizations 


\section{Introduction}

\subsection{Background of the Study}

The competitiveness of today's business environment is rapidly increasing than it has been in the past decades. The more sellers of a similar product or service will lead to have a more competitive business environment in which the organizations have to compete. Therefore, organizations are expected to respond rapidly, effectively and efficiently to face the changes in the market place in order to achieve organizational success.

In order to achieve organizational success, an organization should have achieved both the financial performance and the operational performance (OPP). Operational performance is the output of an organization driven by operations towards goal achievement financially, operational wise and organizational effectiveness. (Venkatraman and Ramanujam, 1986). Operational performance is one of the main aspects of organizational performance. Furthermore, it is the performance of the company against prescribed standards such as waste reduction, productivity, regulations etc. In a rapidly changing competitive world, there is a need to focus on operational performance in order to gain competitive advantage.

In Sri Lankan context, the manufacturing sector is a significant contributor to the economy. Among them large scale enterprises are playing a vital role. It has been found that when analyzing the present contribution of this sector in the national economy, it is clear that the sector has not achieved desired level of contribution when compared with other developed and developing countries in the region. So, there seems to be a vast opportunity for Sri Lanka to harness the opportunity by developing this vital sector.

TQM is an important aspect in the modern business environment because it is a management approach that seeks to promote the long term success of an organization along with the customer satisfaction. In TQM, all members in an organization provide their contribution in order to improve the process, products and services and the culture which they used to work in and TQM uses different strategies, data and effective communication modes to integrate the quality discipline 
in to the culture and the activities of an organization. TQM utilizes both quantitative (technical) methods and human resource (behavioral) practices to improve material and service inputs, intraand inter organizational processes, and to sharpen the focus on meeting customers' needs. (Forker, 1997).

Therefore, the aim of this research is to identify the impact of TQM practices on operational performance of the large scale manufacturing organizations in Sri Lanka based on the theoretical underpinnings of total quality management theory and the resource based view.

\subsection{Problem Statement (Research Gaps)}

One of the major issues that is existing in large scale manufacturing organizations in Sri Lanka is not achieving the desired level of operational performance during their peak seasons. According to the primary data gathered by the researcher, it is clear that the high cost, lack of flexibility, issues with the quality level are the main reasons for this problem. The aim of the research is to find solutions for this performance gap that has been identified by the researcher.

To the best of knowledge, up to date limited researchers have identified the impact of total quality management practices on operational performance of the large scale manufacturing organizations in Sri Lanka. Due to this, it is important to identify the relationship between TQM and operational performance since there are many people who will be affected by this.

The empirical gap that has been identified by the researcher is few of the previous researchers have considered the impact of TQM on operational performance in Sri Lankan context. But up to best of knowledge, few of the researchers have identified the relationship between TQM, on operational performance in large scaled manufacturing organizations in Sri Lanka. There are researchers who have tested the impact of TQM on operational performance in other countries. But the impact identified is unclear as some of the researchers argue that there is a significant positive relationship where as some researchers argue that the relationship is negative or 
insignificant. The researcher tries to find a clear solution for this theoretical gap.

Therefore this study will address the performance gap, empirical gap (contextual gap) and the theoretical gap by evaluating the impact of total quality management practices on operational performance with compliance to the large scaled manufacturing organizations in Sri Lanka.

\subsection{Research Questions}

1. Do TQM practices have an impact on operational performance in large scaled manufacturing organizations in Sri Lanka?

2. What is the individual impact of six indicators of TQM practices on operational performance in large scaled manufacturing organizations in Sri Lanka?

\subsection{Research Objectives}

1. To study the impact of TQM on operational performance in large scaled manufacturing organizations in Sri Lanka

2. To explore the level of individual impact of the six indicators of TQM on operational performance in large scaled manufacturing organizations in Sri Lanka.

\subsection{Research Hypothesis}

1.5.1 Relationship between Total quality management and operational performance

According to the past literature it is clear that, there are many factors that have an impact on TQM practices on operational performance. As per the findings of Alamri et al. (2014), Almansour (2015) and Al-Damen (2017), it is evident that there is a positive relationship between TQM and operational performance. But since that studies have not clearly addressed the gaps that identified in the present study, this study can hypothesize:

Alternative hypothesis H1: TQM has an impact on operational performance 
1.5.2 Relationship between six indicators of TQM practices on operational performance

Various scholars have identified the impact on TQM indicators on operational performance in different ways. Therefore, this study aims to address the unclear theoretical gap.

Zahari and Zakuan (2016) stated that there is a positive relationship between leadership and operational performance. But in contrast, Jaafreh and Al-abedallat (2013) found that employees had a negative perception towards leadership attributes. In order to find a clear conclusion, this study can hypothesize;

Alternative hypothesis HI (a): Leadership (LER) has an impact on operational performance

Ahmad and Schroeder (2003) suggested that the human resource management practices including people management lead to increase the organizational performance of the organizations. As this study focus on improving the operational performance in organizations, it can be hypothesized that;

Alternative hypothesis HI (b): people management (PEM) has an impact on operational performance

Sadikoglu and Olcay (2014) found that process management lead the organizations to improve the total quality management of the organization and in addition to that Ngambi and Nkemkiafu (2015) stated that process of the organization is a critical factor to ensure the TQM and operational performance. Therefore, this study can hypothesize;

Alternative hypothesis HI (c): Process management (PROM) has an impact on operational performance

Khanna, Sharma and Laroiya (2011) stated that there is a positive relationship between customer focus and operational performance in an organization and that study was based within the Indian manufacturing firms. In the current study, the aim is to fill the contextual gap by addressing the customer focus on Operational performance in large scale manufacturing organizations in Sri Lanka. Therefore, this study can hypothesize; 
Alternative hypothesis $H I(d)$ : Customer focus $(C F)$ has an impact on operational performance

According to Evanz and Lindsay (1995), the strategic planning focuses on the organizations strategic and business planning and deployment of plans, along with the attention to customer and operational performance requirements. Therefore, it is essential to identify the impact of strategic planning on operational performance in an organization. As a result of this, this study can hypothesize,

Alternative hypothesis HI (e): Strategy planning (SP) has an impact on operational performance

According to Malcom Baldrige National Award Critreia (1995), the information analysis supports the organizations to improve the performance of the organization. Since this study focus on the improvement of operational performance, it can be hypothesized;

Alternative hypothesis $H I(f)$ : Information analysis (IA) has an impact on operational performance

\subsection{The Significance of the Study}

This research studies the impact of total quality management practices on the operational performance in large scale manufacturing organizations in Sri Lanka which will be beneficial for both practitioners and the academia. The study, further investigates the dimensions of total quality management practices through an extensive literature review. Therefore, the significance of this study can be emphasized as the theoretical as well as the contextual contribution.

This study aims to cater the unclear theoretical gap, by evaluating the impact of total quality management practices on operational performance, considering the variables like, leadership, customer focus, process management, people management, information analysis and the strategy planning. The operational performance has been measured through the variables such as cost, flexibility, delivery, quality and the dependability.

Above mentioned aspect has not been empirically analyzed previously as a single model in large scale manufacturing organizations in Sri 
Lanka. Therefore, the significance of this study is that this research helps to create a new knowledge to the existing literature by addressing both the theoretical gap and the empirical gap.

Moreover, it is important to identify the effect of total quality management practices on operational performance because, ultimately it helps to achieve organizational performance effectively and efficiently which will lead to achieve competitive advantage. Therefore, this also can be considered as a significance of this study.

It has no doubt that large scale manufacturing organizations in Sri Lanka holds a significant position in Sri Lanka's economy. Therefore, it is important to identify the effect of TQM practices on the operational performance. Hence, this study will also contribute immensely to the Sri Lankan industrial sector and ultimately to the Sri Lankan economy. Therefore, in a nut shell, the study will be beneficial for the practitioners, researchers and the policy makers in a broad way and it will ultimately help for the economy of the country.

\subsection{Research Overview}

In order to address the research problem explained in the first section, this study points towards the development of a theoretical model that suggests the impact of TQM practices on operational performance. The second section of the article elaborates the past literature on TQM and Operational performance. These literature acts as a foundation to develop the research model and the hypotheses as an effort to seek answers for the research questions. The third section is devoted to methodology being used in the article. Data collected from the survey is then examined and analyzed based on the structural equation modeling (SEM) approach proposed in the section four. Section five is committed to discuss the findings with available literature both locally and globally. Finally section six consists of the conclusions and discuss the possible managerial implications of the research that are relevant and related to the research problem and the context. 


\section{Literature Review}

\subsection{Theoretical Foundation of the Study}

\subsubsection{Total Quality Management Theory}

Total quality management theory was established by Deming (1991) and Juran in 1931. This theory was established on the foundation of customer satisfaction (Arumugam et al, 2008). Anyango et al. (2012) assert that quality is perceived from different perspectives by different customers. Deming (1991) has stated that if a company focuses on cost, the problem is that cost rise while quality deteriorates. Deming's system of profound knowledge consists of system appreciation, variation knowledge, knowledge theory and the psychology knowledge. And also he has found 14 principles to define total quality management. Crobsy 's (1979) four absolutes are define quality as adherence to requirements, Prevention is the best way to ensure quality, and Zero Defects (mistakes) is the performance standard for quality and Quality is measured by the price of nonconformity. Joseph Juran is responsible for what has become known as the "Quality Trilogy." The quality trilogy is made up of quality planning, quality improvement, and quality control. If a quality improvement project is to be successful, then all quality improvement actions must be carefully planned out and controlled. (Bowen et al., 1994). In general, total quality management will lead to improve the performance of an organization either operationally or financially. Therefore, this theory is applicable in this study on the basis of impact of TQM on operational performance.

\subsubsection{Resource Based View}

The resource based view, is an approach of strategy formulation aimed at attaining competitive advantage based on an organization's resources. This theory was mainly developed in 1980s and 90s. Under this view, Organizations look for competitive advantage within themselves as opposed to looking for competitive environment outside (Barney, 1991) The resources based view of strategy also creates a frame work for the executives to think about their strength and weakness, understand marketing issue that helps to improve corporate performance (Falkenreck, 2010). 
A model developed by Barney described the source of competitive advantage to be residing in resources both tangible and intangible that must be heterogeneous and immobile, not imitable and nonsubstitutable with great effort. TQM can lead to the improvement of performance by encouraging the development of assets that are specific, produce socially complex relationships which are steeped in the history and culture of the company and generate tacit knowledge (Barney, 1991).TQM can further the development of a series of routines and form the fabric Of behavior in the organization, which result from a process of learning and experience within the company itself (Winter, 1994). Thus, TQM generates a wealth of distinctive competencies within the company that encourage a more effective and efficient development of the operations within the organization. Therefore, resource based view is also can be used for this study in order to identify the relationship between total quality management practices on the operational performance of the organizations

\subsection{Operational Performance}

Performance is made of the actual outputs or results of an entity as compared against its intended goals and objectives (Walker, et al., 2009). Organizational Performance can be evaluated in terms of either operational or financial performances. Examples of factors that promote operational performance include productivity, level of output, employees' performance, and customer satisfaction (Kuo et al., 2009). On the other hand, the enterprise's financial performance is measured in terms of revenue growth, profit margin, and the growth of the organization (Jerome, 2013). In the present business environment, the performance of the organization is measured using financial gains, and employee and client satisfaction. Ho (2008) argued that the effectiveness and efficiency of firm's operations affect both operational and financial performance. According to Sigei, (2014) there are many factors that can be used to measure performance that include market and financial results, operating performance involving efficiency and effectiveness of an organization, employee performance, social responsibility and customer results 
According to Andy Neely (2009), there are five main operational performance objectives: speed, quality, costs, flexibility, and dependability. In a rapidly changing competitive world, there is a need to focus on operational performance in order to gain competitive advantage. Therefore, the study will measure operations performance in terms of cost, quality, flexibility, speed and the dependability.

\subsection{Total Quality Management}

Research by Flynn et al. (1995), identified the most influential elements of TQM as intangible and behavioral. Additionally, the study found TQM as a soft variable consisting of customer focus, human resource focus and leadership as these are invisible but have a direct impact on company's performance (Flynn et al., 1995; Powell, 1995). Following a comprehensive review of the literature it was eminent that most of the researchers evaluated TQM through six variables. These variables were; strategic planning, leadership, customer focus, information and analysis, process management and people management (Terziovski and Samson, 1999). According to Curkovic et al., (2000) the most successful elements of TQM were customer focus, employee empowerment and top management support (Mehmood et al., 2014). Talib (2013) claimed no research explicates the key elements of TQM. It becomes hard to identify the exact elements of TQM based on the above criteria (Hoang et al., 2006). Nevertheless, the majority of the researchers agreed that the most significant elements of TQM were customer focus, process approach, supplier partnering, employee involvement, continuous improvement, top management support and strategic quality management. Hassan et al., (2014) noted that TQM practices of top management/leadership, customer focus, people management, process management, and strategy planning and information analysis affects the organizational performance. At the same time, almost in all the research studies TQM practices have been assessed using the Malcom Baldrige National Quality award criteria (1995) which consists of six factors namely, top management/leadership, customer focus, people management, process management, and strategy planning and information analysis. 


\subsection{Relationship between Variables}

Research studies that have been carried frequently has identified the relationship among TQM and organizational performance in many ways. Many researchers conclude that the effect on TQM on quality performance is significant for both the manufacturing and the services firms. The study of Lai and Cheng (2005) indicates that high levels of quality management implementations and marketing implementation alignment are conducive to achieve a high level of organizational performance through motivation, productivity performance, societal and marketing performance. But, effect on TQM and operational performance is scarily researched. (Perera and Kuruppurachchi, 2010). As per the limited literature, most of the researchers have found that there is a positive relationship among TQM and the operational performance (Sarkees and Hulland, 2009). But according to the available data, TQM and operational performance have not been tested in large scaled enterprises in Sri Lanka. Therefore, the main purpose of this research is to identify the impact on total quality management practices on manufacturing organizations in Sri Lanka by filling the contextual gap.

\subsection{Conceptual Framework}

The following framework is developed with the aim of finding solutions to the research problem. The model has been established based on the literature on TQM and OPP. Hence, it will hypothesis the relationships of the study and simplify the understanding of the study context. 
TQM

(MBNQA, 1995)
OPERATIONAL

PERFORMANNCE

(Neely, 2009)

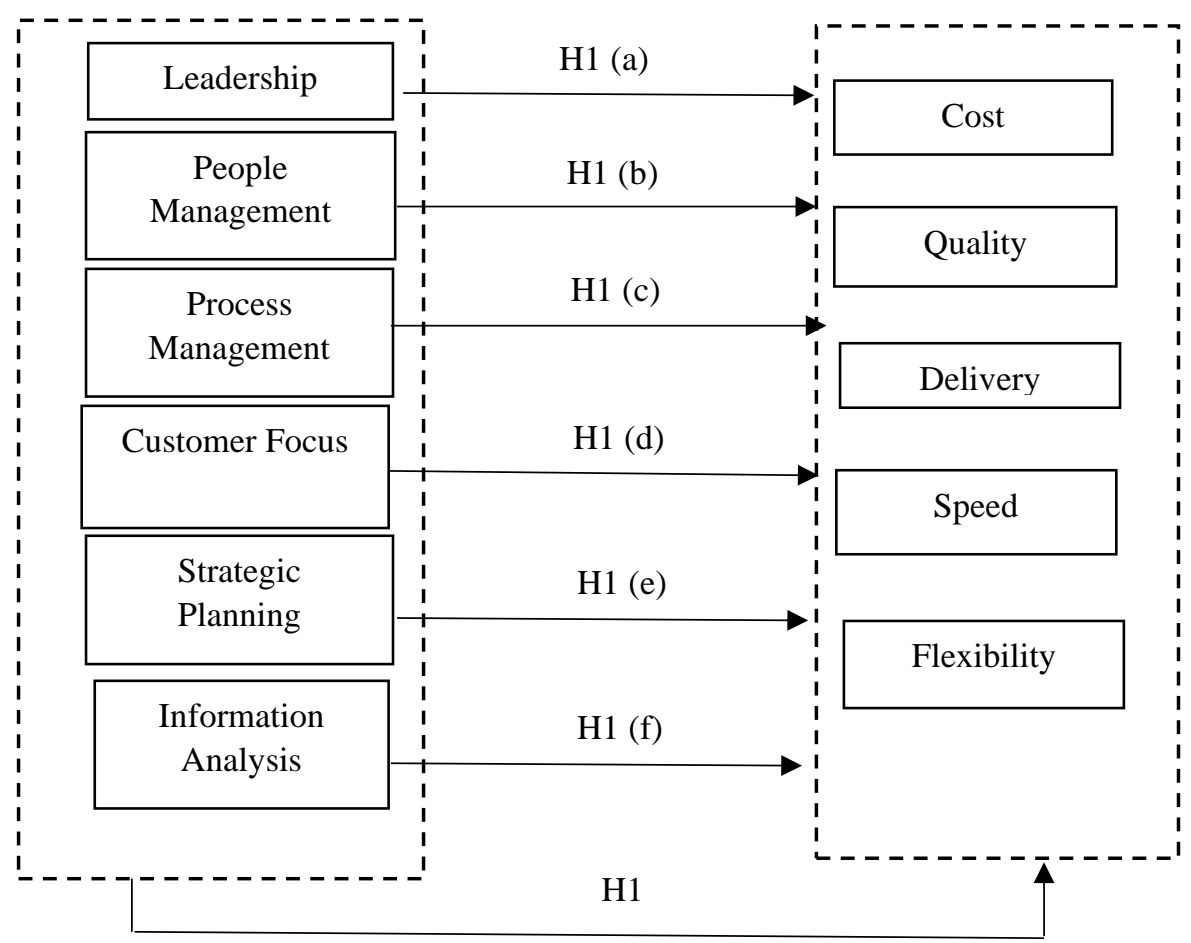

Source: Author Constructed

\section{Figure 1: Conceptual Framework}

\section{Research Methodology}

\subsection{Research Design}

In order to understand the process of research, the concept of "Research Onion" which was produced by Saunders et al. (2007), was used. This study would follow positivism where that philosophy allows to observe social reality that will lead to credible data to answering to the gathering of facts. (Mark, Philip, \& Adrian, 2009). And the interpretations of the findings of this research will be quantified and generalized using statistical analysis. The researcher used the deductive approach by developing a conceptual framework from the literature to test the collected data. For this study, the 
researcher decided to use survey research strategy which is often linked with the deductive approach as the research strategy. Mono method is used in this study as the research choice where it gathers only quantitative information. The cross-sectional time horizon is adopted when conducting this research as the research is to be completed over particular time duration.

\subsection{Population and Sampling Procedure}

The population that the study is relying on is the listed companies in Ceylon chamber of commerce. Since Ceylon Chamber of Commerce does not categorize the companies under them as large scale organizations, the definition declared by the OECD (Organization for economic cooperation and development) report will be considered in this study.

\section{Table 1: Classification of Businesses}

\begin{tabular}{|l|l|l|l|l|l|}
\hline Sector & Criteria & Micro & Small & Medium & Large \\
\hline Manufacturing & $\begin{array}{l}\text { Number of } \\
\text { employees }\end{array}$ & $\begin{array}{l}\text { Less } \\
\text { than 10 }\end{array}$ & $10-49$ & $50-249$ & $\begin{array}{l}\text { More } \\
\text { than } \\
\mathbf{2 5 0}\end{array}$ \\
\hline
\end{tabular}

Source: OECD (2020)

At present there are 626 large scale manufacturing companies and the sample size was selected as 220. The sample unit of analysis is the listed large scale organizations in manufacturing sector. The sample unit covers industries of agro processing and beverages, high tech industry, machinery and equipment, pharmaceuticals, apparels and rubber based products.

The researcher will use simple random sampling as it is highly generalizable, can be easily understood and reliable. Unit of analysis will be organizations.

The majority of information required for this study is to be taken from employees working at the managerial level. Therefore, it is decided that the managers would be the respondents in this study. Many studies are based on a single respondent from each company. 
For example, the studies conducted by Hussain, Akhtar and Butt (2009) and Bou-Llusar et al. (2009) are based on a single response, and the respondents were the quality or production managers. Similarly, this study is based upon a single response from each company and respondents were quality or production managers.

The current study used structural equation modeling (SEM) as the analysis technique as it utilizes a confirmatory rather than an exploratory data analysis, which helps it to fit with hypothesis testing, can provide explicit estimates of error variance parameters and can handle measurement error problems much better than traditional multivariate procedures and can analyze both observed and unobserved measurements while traditional method can only analyze observed measurements.

SEM is the most suitable data analysis technique for the present study to test the hypothesis since SEM allows for analyzing both observed and unobserved variables whereas traditional methods such as regression analyze only observed measurements.

However, with respect to different features of SEM, it is difficult to develop general guidelines regarding the sample size. (MacCallum et al, 1999). Moreover, various rules of thumb have been noted as;

1. The minimum sample size is 100 or 200 (Boomsma and Hoogland, 2001)

2. 5 or 10 observations per estimated item are necessary (Bentler and Chou, 1987)

According to Hair et al, 2010, five cases per variable would be adequate when the latent variables have multiple indicators. Therefore, present study deals with five contrast along with 44 indicators and therefore 220 would be minimum sample requirement for the study.

\subsection{Pre Test and Pilot Test}

The questionnaire, once developed, was sent to five people three operations managers and two production managers in five manufacturing firms for their comments. These participants were given the questionnaire and asked to examine it for meaningfulness, 
relevance and clarity. After the pre-test, 30 respondents were given edited questionnaire for the pilot test. The purpose of the pilot test is to identify and eliminate potential problem in the questionnaire design (Malhotra and Peterson 2006) and to examine the validity and reliability of the measures used in the questionnaire (Sekaran and Bougie 2009). The 30 questionnaires were analyzed using the statistical package SPSS package version 23. The reliability of the measures were checked for each construct through Cronbach's Alpha. A satisfactory level of reliability can be obtained through a Cronbach's Alpha of 0.7 (Nunnally and Bernstein 1994, p.245). Therefore, questions relating to depicted in Table 2 demonstrate internal consistency

Table 2: The measures of reliability of questions in pilot-test questionnaire

\begin{tabular}{|l|l|}
\hline Construct & Cronbach's Alpha \\
\hline Leadership & 0.744 \\
\hline Strategic planning & 0.707 \\
\hline Customer focus & 0.831 \\
\hline Information analysis & 0.785 \\
\hline People management & 0.845 \\
\hline Process management & 0.823 \\
\hline Cost & 0.728 \\
\hline Speed & 0.714 \\
\hline Flexibility & 0.703 \\
\hline Quality & 0.787 \\
\hline Dependability & 0.725 \\
\hline
\end{tabular}

Source: Survey Data (2020)

\section{Data Presentation and Analysis}

\subsection{Data Analysis}

Like any statistical method, SEM features a number of assumptions which should be met or at least approximated to ensure the trustworthy results (Kline, 2011). Given 279 questionnaires deemed valid for data analysis, this section further examines the extent to 
which data meet these assumptions. In particular, the following data issues are examined: missing values, outliers, multivariate assumptions, statistics for scale purification and the reliability test and model validation. There were no missing values and outliers.

Normality of the study was achieved since all the skewness statistics are less than one and kurtosis statistics are ranging within in -2 and +2 . Shapiro Wilk's test $(\mathrm{P}>0.05)$ Shapiro and Wilk, (1965). Therefore, the assumption of normality is validated and thus the analysis could be preceded using AMOS. This is because normality is one of the basic assumptions that need to be satisfied in SEM analysis. (Byrne, 2010). Based on the ANOVA table, sig value of the deviation of the linearity, which is greater than 0.05 , in all variables, it can be concluded that there is a linear relationship in the data set Homoscedasticity is another important assumption in multivariate analysis. In the study, normal probability plot, and scatter plot were used to test the linearity and homoscedasticity. As the tolerance values are greater than 0.1 and the VIF values are less than 10 , it can be concluded that there is no multicollinearity in existence.

\subsection{Adequacy of the Sample}

The Kaiser-Meyer-Olkin is the measure of sampling adequacy, which varies between 0 and 1 . A value indicates that the sum of partial correlations, indicating diffusion in the pattern of correlations. Hence, factor analysis is like to be inappropriate. A value close to 1 indicates that patterns of correlations are relatively compact and so factor analysis should yield distinct and reliable factors. Kaiser and Rice (1974) recommends accepting values greater than 0.5 are acceptable. Furthermore, values between 0.5-0.7 are mediocre, values between 0.7-0.8 are good, values between 0.8-0.9 are great and values above are superb. (Hutcheson and Sofroniou 1999).

Bartlett's measure tests the null hypothesis that the original correlation matrix is an identity matrix. Bartlett's Test of Sphericity relates to the significance of the study and thereby shows the validity and suitability of the responses collected to the problem being addressed through the study. For factor analysis to be recommended suitable, the Bartlett's Test of Sphericity should be less than 0.05 


\section{Table 3: Test adequacy of sample}

KMO and Bartlett's Test

\begin{tabular}{|ll|l|}
\hline \multicolumn{2}{|l|}{ Kaiser-Meyer-Olkin Measure of Sampling Adequacy. } & .898 \\
Bartlett's Test of Sphericity & Approx. Chi-Square & 1126.522 \\
& Df & 78 \\
& Sig. & .000 \\
\hline
\end{tabular}

Source: Survey Data (2020)

As per the table it is clear that Kaiser-Meyer-Olkin value is more than 0.5 and therefore it can be concluded that the factor analysis is appropriate for the data set. At the same time Bartlett's Test of Sphericity is highly significant as the value is less than 0.05 .

\subsection{Structural Equation Modeling (SEM)}

In general, a SEM model is comprised of two sub models; a measurement model and the structural model (Byrne, 2010). Measurement model defines the relationship between the observed variable and the latent constructs and the structural model presents the relationship among the latent constructs. The two-step SEM process has also been considered as a good practice in the conduct of SEM analysis (Schumacker and Lomax 2010; Hair et al., 2010).

Confirmatory factor analysis (CFA) procedures are employed to examine the measurement model which includes the observed variables and the latent constructs. This is to test how well the observed variables can measure their associated latent constructs. The causal structure of the proposed model is examined to assess the extent to which these latent constructs are related.

According to Hair et al, (2010), it is recommended that when assessing the fit of a measurement model, researchers should report one absolute fit index and one incremental index besides the chisquare value and the degrees of freedom. Accordingly, current study, besides the Chi square, the GFI and RMSEA were reported as absolute fit indices and CFI and TLI were reported as incremental fit indices. 


\section{Table 4: SEM GOF Indices}

\begin{tabular}{|l|l|}
\hline Index & Acceptable scale for good and adequate fit \\
\hline CMIN/DF & $1-3$ \\
\hline GIF & $\begin{array}{l}\text { Values }>0.95 \text { indicate good fit Values between } 0.90-0.95 \\
\text { indicate adequate fit }\end{array}$ \\
\hline RMSEA & Values between $0.05-0.08$ indicate adequate fit \\
\hline CIF & $\begin{array}{l}\text { Values between } 0-1 \text { ( above } 0.9 \text { usually associated with a } \\
\text { model that fits well }\end{array}$ \\
\hline
\end{tabular}

Source: Hair et al. (2010)

\subsection{Confirmatory Factor Analysis}

Firstly, the initial measurement model was drawn. The measurement model "specifies the indicators for each construct, and enables an assessment of construct validity" (Hair et al., 2010). There are 44 observed variables based on the conceptual model namely, LER 1 to LER 4, SP1to SP 4, CF 1 to CF 6, IA 1 to IA 4, PEM 1 to PEM 5, PROM 1 to PROM 6, OC 1 to OC 4, OS 1 to OS 3, OF 1 to OF 2, OQ 1 to OQ 3 and OD 1 to OD 3. There are 11 latent variables .For the purpose of CFA, all the constructs are allowed to correlate with all other constructs, while the measured variables are allowed to load on only one construct each and the error terms, (Byrne, 2010). All regression weights are above 0.5 of all items except SP1, CF 4, CF1.CF3 and OC 1. All $t$ values were significant at $p<0.001$ of all items. In the current study the initial model shows, Comparative fit index $(\mathrm{CIF})=0.897$ Goodness fit index $(\mathrm{GIF})=0.803 \mathrm{CMIN} / \mathrm{DF}=$ 1.451 Root mean of square error of approximation $($ RMSEA $)=0.040$ Therefore, the initial measurement model required further modification so as to better fit the data. Stepwise deletion of items below 0.5 factors loading was applied to further refine the initial model and then the final measurement model was developed.

The final refined measurement model was obtained after removing 5 items namely, OC1, CF4, SP1, CF3and CF 1 which had standard regression weights less than 0.5 at 5 stages. After that, all the standard regression weights were above 0.5 . All the $t$ values were significant at 
$\mathrm{p}<0.001$. Comparative fit index $(\mathrm{CIF})=0.909$ Goodness fit index $(\mathrm{GIF})=0.809 \mathrm{CMIN} / \mathrm{DF}=1.471$ Root mean of square error of approximation $($ RMSEA $)=0.041$, was achieved showing a good level of fit compared to the initial measurement model.

\subsection{Assessing Reliability}

Reliability test provides an indication of internal reliability of indicators used to measure constructs. In other words, it assesses how highly interrelated the indicators are used together to measure their associated constructs (Hair el al, 2010). Given the recommended Cronbach's alpha greater than 0.7 (Kline, 2011), Table 5 shows the acceptable reliability for each dimension.

Table 5: Reliability of measurement items

\begin{tabular}{|l|l|l|}
\hline Construct & Measurement & Cronbach's alpha \\
\hline Leadership & LER & 0.774 \\
\hline strategic planning & SP & 0.723 \\
\hline Customer focus & CF & 0.703 \\
\hline Information analysis & IA & 0.785 \\
\hline People management & PEM & 0.845 \\
\hline Process management & PROM & 0.823 \\
\hline Cost & OC & 0.781 \\
\hline Speed & OS & 0.714 \\
\hline Flexibility & OF & 0.714 \\
\hline Quality & OQ & 0.787 \\
\hline Dependability & OD & 0.725 \\
\hline
\end{tabular}

Source: Survey Data (2020)

\subsection{Convergent Validity and Discriminant Validity}

Convergent validity was measured using factor loading, composite reliability (CR) and average variance extracted (AVE). As shown in the table, all the $\mathrm{CR}$ values are greater than 0.5 and some of the AVE values are above 0.5 and some are approximately equals to 0.5 . 
Table 6: Convergent validity

\begin{tabular}{|l|l|l|l|}
\hline Dimension & Factor loading & CR & AVE \\
\hline LER & $0.632-0.711$ & 0.779 & 0.469 \\
\hline SP & $0.640-0.724$ & 0.727 & 0.471 \\
\hline CF & $0.500-0.819$ & 0.715 & 0.465 \\
\hline IA & $0.655-0.744$ & 0.785 & 0.478 \\
\hline PEM & $0.590-0.815$ & 0.847 & 0.528 \\
\hline PROM & $0.514-0.687$ & 0.819 & 0.434 \\
\hline OC & $0.644-0.842$ & 0.792 & 0.562 \\
\hline OS & $0.534-0.820$ & 0.789 & 0.48 \\
\hline OF & $0.741-0.751$ & 0.715 & 0.557 \\
\hline OQ & $0.636-0.876$ & 0.803 & 0.581 \\
\hline OD & $0.578-0.762$ & 0.793 & 0.494 \\
\hline
\end{tabular}

Source: Survey Data (2020)

To assess discriminant validity, the square of the correlation estimates between the each construct was compared with the AVE of each constructs. The AVE value of each construct should be higher than the square of the correlation estimates between that construct and other constructs. Except the values between LER-SP and PEMIA, all the other values are lower the agreed limit. Though they are having lower convergent validity, they maintain satisfactory levels of composite reliability. And also the correlation coefficients among the study constructs do not exceed 0.85 (Kline, 2011). Therefore, all the constructs in the study represent different concepts and there are no problems with discriminant validity.

\subsection{Structural Models}

In SEM, the structural model defines the relationships among the latent variable constructs (Byrne, 2010).thus, the structural model helps to specify the manner by which specific latent constructs directly or indirectly affect changes in the values of other latent constructs in the model (Byrne, 2010). In the current study, the proposed structural model is composed of two latent variables, of which one is exogenous (TQM) and the one is endogenous (OPP). 
Figure 2 presents the structural model and the proposed relationships among the constructs.

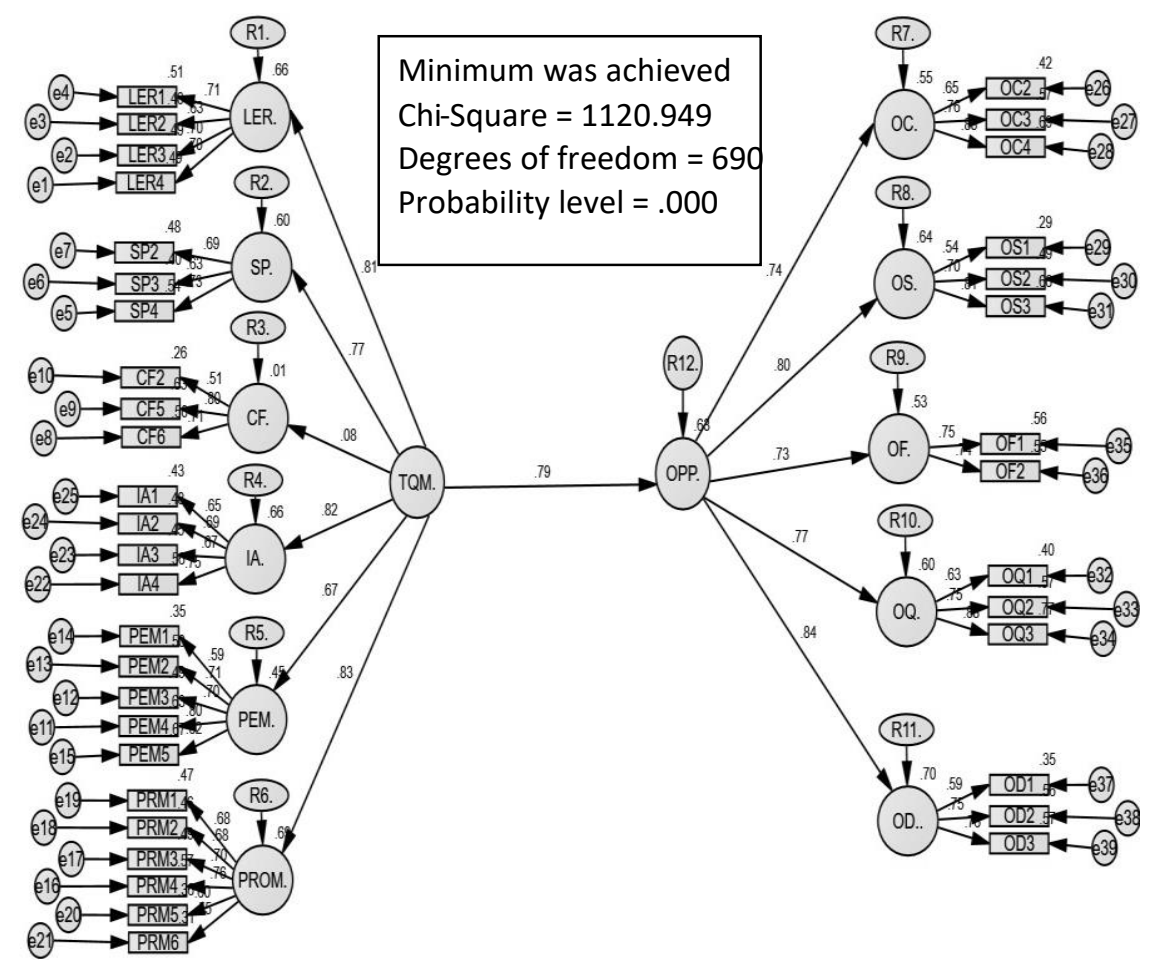

Source: Survey Data (2020)

\section{Figure 2: The Structural Model for TQM and OPP}

The overall fit of the structural model was assessed so as to evaluate the extent to which the proposed causal relationships between the latent constructs fit the research data. It is recommended that a study reports one absolute fit index and one incremental index besides the Chi-square value and the degrees of freedom (Hair et al., 2010). Accordingly, besides the Chi-square, the GFI and RMSEA were reported as absolute fit indices, and the CFI and TLI were reported as incremental fit indices. Thus, the overall fit of the structural model was assessed with the same set of fit indices as those of the measurement models. The fit indices indicated that the structural model had a good fit with the data $\quad \chi^{2 / \mathrm{df}}=1.621, \mathrm{CFI}=0.901 \mathrm{GFI}$ $=0.763$ RMSEA $=0.047$ thus supporting the basic theoretical model of the study. 


\subsection{Hypotheses Testing}

Table 7 presents the results of testing the hypothesized direct relationships among Total quality management (TQM), and Operational performance (OPP). The table also includes the standardized path coefficients, $t$-values, and the corresponding significance levels.

Table 7: Hypotheses Test Results for the H1

\begin{tabular}{|l|l|l|l|l|}
\hline Path & Hypothesis & $\begin{array}{l}\text { Standardized } \\
\text { Coefficient }\end{array}$ & $\begin{array}{l}\text { P } \\
\text { value }\end{array}$ & Result \\
\hline $\begin{array}{l}\text { TQM } \rightarrow \\
\text { OPP }\end{array}$ & $\begin{array}{l}\text { H1: TQM has a significant } \\
\text { impact on operational } \\
\text { performance. }\end{array}$ & 0.793 & $0.000^{* *}$ & Accept \\
\hline ** P $<0.05$ & & & \\
\hline
\end{tabular}

\section{Source: Author Constructed}

Hypothesis 1 investigated the relationship between Total quality management (TQM) and Operational performance (OPP). It was hypothesized that there would be a relationship Total quality management (TQM) and Operational performance (OPP). The results, demonstrated positive and significant paths from Total quality management (TQM) and Operational performance (OPP). ( $\beta$ $=0.793 p=0.000$ ). Thus, hypotheses 1 was supported.

Figure 3 shows the structural model for hypothesis ( H1 (a), H1 (b), H1 (c), H1 (d), H1 (e), H1(f)) and the proposed relationships among leadership, people management, process management, customer focus, strategy and quality planning and information analysis with operational performance. Thus, the overall fit of the structural model was assessed with the same set of fit indices model had a good fit with the data $\chi^{2 / \mathrm{df}}=2.261 \mathrm{CFI}=0.799 \mathrm{GFI}=0.754 \mathrm{RMSEA}=$ 0.067 as those of the measurement models. The fit indices indicated that the structural thus supporting the basic theoretical model of the study. 


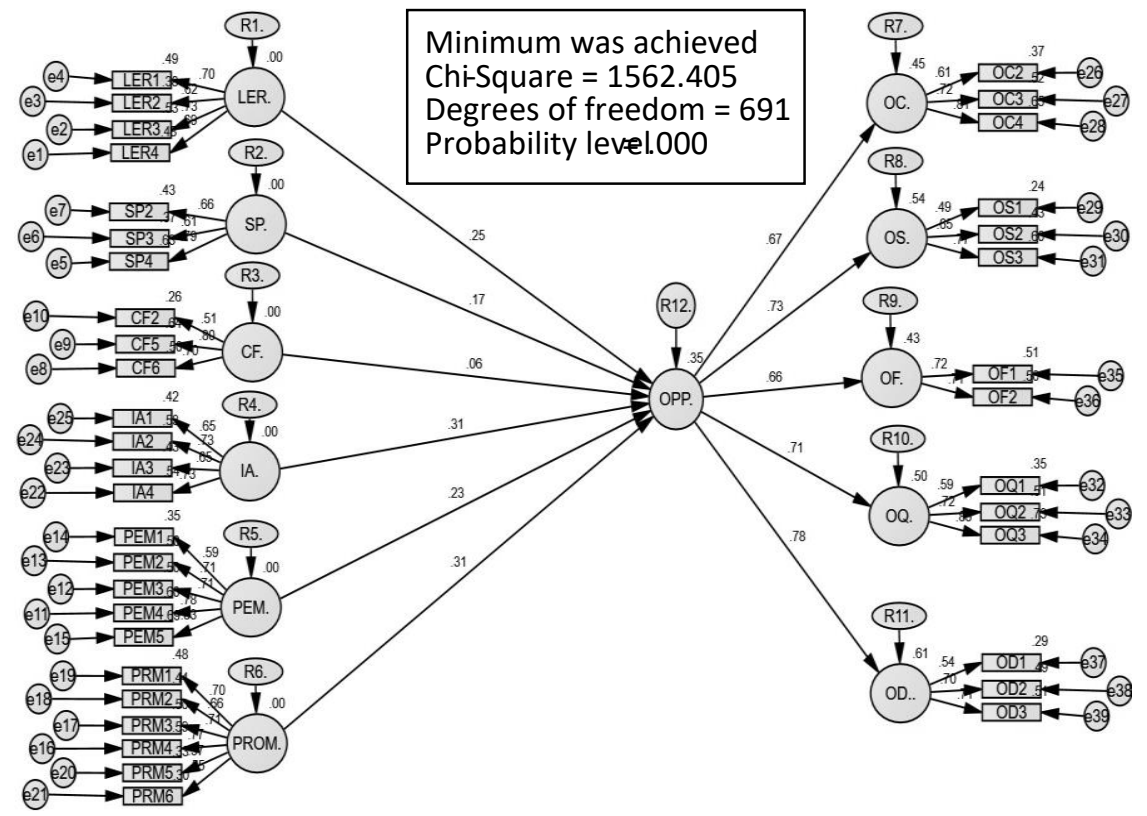

Source: Survey Data (2020)

Figure 3: The Structural Model for TQM indicators and OPP

Table 8 presents the results of testing the hypothesized direct relationships among leadership, people management, process management, customer focus, strategic planning and information analysis with operational performance. The table also includes the standardized path coefficients, $t$-values, and the corresponding significance level. 
Table 8: Hypotheses Test Results for H1 (a), H1 (b), H1 (c), H1 (d), H1 (e), H1 (f)

${ }^{* *} \mathrm{P}<0.05$

\begin{tabular}{|c|c|c|c|c|}
\hline Path & Hypothesis & $\begin{array}{l}\text { Standar } \\
\text { dized } \\
\text { co- } \\
\text { efficient }\end{array}$ & $\begin{array}{l}\text { p- } \\
\text { value }\end{array}$ & Result \\
\hline LER $\rightarrow$ OPP & $\begin{array}{l}\text { H1 (a): Leadership has a } \\
\text { significant impact on } \\
\text { operational performance. }\end{array}$ & 0.248 & $0.002^{*}$ & Accept \\
\hline $\mathrm{PEM} \rightarrow \mathrm{OPP}$ & $\begin{array}{l}\text { H1(b):People } \\
\text { management has a } \\
\text { significant impact on } \\
\text { operational performance }\end{array}$ & 0.235 & $0.001^{*}$ & Accept \\
\hline $\mathrm{PROM} \rightarrow \mathrm{OPP}$ & $\begin{array}{l}\text { H1(c):Process } \\
\text { management has a } \\
\text { significant impact on } \\
\text { operational performance }\end{array}$ & 0.314 & $0.000^{*}$ & Accept \\
\hline $\mathrm{CF} \rightarrow \mathrm{OPP}$ & $\begin{array}{lr}\text { H1 }(\boldsymbol{d}) \text { : } \text { Customer focus } \\
\text { has a significant impact } \\
\text { on } \\
\text { performance }\end{array}$ & 0.064 & $0.037^{*}$ & Accept \\
\hline $\mathrm{SP} \rightarrow \mathrm{OPP}$ & $\begin{array}{lr}\text { H1( }(\boldsymbol{e}) \text { : } \text { Strategy planning } \\
\text { has a significant impact } \\
\text { on } & \text { operational } \\
\text { performance } & \end{array}$ & 0.174 & $0.021^{*}$ & Accept \\
\hline $\mathrm{IA} \rightarrow \mathrm{OPP}$ & $\begin{array}{l}\boldsymbol{H 1}(\boldsymbol{f}) \text { : Information } \\
\text { analysis has a significant } \\
\text { impact on operational } \\
\text { performance }\end{array}$ & 0.311 & $0.000^{*}$ & Accept \\
\hline
\end{tabular}

Source: Author Constructed

Hypothesis H1 (a) investigated the relationship between Leadership (LER) and Operational performance (OPP). It was hypothesized that there would be a relationship between Leadership (LER) and Operational performance (OPP). The results, demonstrated positive and significant paths from Leadership (LER) and Operational 
performance (OPP). $(\beta=0.248 p=0.002)$. Thus, hypotheses H1 (a) was supported.

Hypothesis H1 (b) investigated the relationship between People management (PEM) and Operational performance (OPP). It was hypothesized that there would be a relationship between People management (PEM) and Operational performance (OPP). The results, demonstrated positive and significant paths from People management (PEM) and Operational performance (OPP). $(\beta=0.235 p=0.001)$. Thus, hypotheses H1 (b) was supported.

Hypothesis H1 (c) investigated the relationship between Process management (PROM) and Operational performance (OPP). It was hypothesized that there would be a relationship between Process management (PROM) and Operational performance (OPP). The results, demonstrated positive and significant paths from Process management (PROM) and Operational performance (OPP). $(\beta=$ $0.314 p=0.000$ ). Thus, hypotheses H1 (c) was supported.

Hypothesis H1 (d) investigated the relationship between customer focus (CF) and Operational performance (OPP). It was hypothesized that there would be a relationship between customer focus (CF) and Operational performance (OPP). The results, demonstrated positive and significant paths from customer focus (CF) and operational performance (OPP). $(\beta=0.064 p=0.037)$. Thus, hypotheses H1 (d) was supported.

Hypothesis H1 (e) investigated the relationship between strategic planning (SP) and Operational performance (OPP). It was hypothesized that there would be a relationship between strategic planning (SP) and Operational performance (OPP). The results, demonstrated positive and significant paths from strategic planning (SP) and Operational performance (OPP). $\quad(\beta=0.174 p=0.021)$. Thus, hypotheses H1 (e) was supported

Hypothesis H1 (f) investigated the relationship between information analysis (IA) and Operational performance (OPP). It was hypothesized that there would be a relationship between information analysis (IA) and Operational performance (OPP). The results, demonstrated positive and significant paths from customer focus (CF) 
and Operational performance (OPP). $\quad(\beta=0.311 p=0.000)$. Thus, hypotheses H1 (f) was supported.

\section{Discussion}

The following section discusses the study results, based on empirical evidences of the hypothesis test, which is organized around the research questions addressed in this article.

\section{Do TQM practices have an impact on operational performance in large scaled manufacturing organizations in Sri Lanka?}

First research question addressed the impact of total quality management practices on operational performance. The results elaborated that total quality management practices were associated with increased operational performance. It is clear that, a good leadership/support of the management, having strategic plans in the organization, focusing more on customer requirements, managing the people in the organization effectively and having an effective process management system will increase the operational performance in manufacturing organizations. This may be due to total quality management practices will help the organizations to reduce costs by eliminating non confirmation and repetitive work, elimination of reworks and repairs. At the same time TQM practices will help the organizations to increase the quality of the products in the manufacturing organizations if there are continuous improvement techniques, training programs on quality and by having quality management systems. If the organization is practicing TQM, they will be able to increase the flexibility in the organization by meeting the varied customer demands in terms of specifications and also having flexible modes of service and product delivery will increases sales and reduce costs which will ultimately increase the operational performance in manufacturing firms. At the same time, TQM practices will help the firms to increase the flexibility in the firm by having less rework and by eliminating bottlenecks in production can reduce lead time to fulfill customer orders. Finally, TQM will enhance economies of scale due to greater efficiency. Ultimately TQM practices may increase the operational performance in 
manufacturing firms. Therefore, it is clear that total quality management practices have a positive impact on operational performance in large scale manufacturing organizations in Sri Lanka. These findings are consistent with the findings of previous research in other contexts in the world and also in the banking industry. Although some researchers argued that there is no relationship between TQM and operational performance, the findings are matching with most of the previous literature. (Martínez-Costa and Martínez-Lorente, 2008; Sarkees \& Hulland, 2009; Hung \& Pradigo, 2008). At the same time this relationship is supported with the Total quality management theory where it discusses total quality management will lead to improve the performance of an organization either operationally or financially. According to literature since there are both negative and positive relationships have been identified by previous researchers, for this unclear problem, the present study's findings add an argument that the effect of Total quality management has a positive impact on the operational performance in Sri Lankan large scale manufacturing organizations.

What is the individual impact of six indicators on TQM practices on operational performance in large scaled manufacturing organizations in Sri Lanka?

The second question of the research addressed the impact of six indicators of TQM practices on operational performance. The six indicators are among leadership, people management, process management, customer focus, strategic planning and information analysis. According to Samson and Terziovski (1999), people management, customer focus and leadership were strongly significant and positive while other three factors were either insignificant or negative. The findings of the current study revealed that all the six indicators are having a positive and a significant impact on operational performance in large scaled manufacturing organizations in Sri Lanka. The result is matching with Chauke et al. (2019) where the researcher has identified all the six indicators are significantly positive. Moreover, among all the six indicators, customer focus shows the lowest positive value (0.064) which is also matching with the researcher Kuruppuarachchi and Perera (2010). According to the 
research findings it can be concluded that all the six indicators namely, leadership, people management, process management, customer focus, strategy planning and information analysis will lead an organization to increase their operational performance.

\section{Conclusion}

\subsection{Conclusion}

This study makes special contribution to the total quality management literature as it provides a clear understanding if impact of total quality management and operational performance

Manufacturing sector is very important to the Sri Lankan economy in terms of employment, output, foreign currency earnings etc. Large scaled manufacturing sector supports the economy to reduce the unemployment as it generates more job opportunities for the society. At the same time, the large scaled manufacturing organizations generate more foreign currency earnings as they are more towards the globalization. In a nutshell, large scaled manufacturing sector plays a vital role in the Sri Lankan economy.

Total quality management practices are used by the most of the large scaled manufacturing organization intentionally or non-intentionally. But there are some organizations in Sri Lanka that do not focus on the total quality management practices. This study is evident that TQM practices leads to increase operational performance in organizations. Therefore, the impact of total quality management on the operational performance of the large scaled manufacturing sector is fundamentally important for face emerging challengers and contributes immensely to the Sri Lankan economy.

Several previous studies have been conducted and which have looked into these dimensions, however, this study enriched the existing literature by filling a gap concerning some disagreements identified in previous investigations, not only regarding the ambiguity of the findings, but also concerning the different interpretations of the concepts studied. Regarding the operational performance, this research analyzed this dimension through five different perspectives, 
namely, cost, quality, flexibility, speed and dependability, whereas most of the researchers do not consider dependability to measure operational performance.

To achieve better operational performance, this study recommends that improvement in adoption of total quality management practices because they have been implemented to a moderate extent in large scaled manufacturing organizations in Sri Lanka. One or two practices of TQM may not bring the desired level of operational performance compared to all practices working in synergy. An integration of all the TQM practices is essential to rip off the benefits of TQM. Employees need to be empowered and made to feel they are involved by top management. Continuous improvement need to be embedded in all processes and job descriptions should include continuous improvement as a responsibility. Top management also should enhance the creation of the right cultures through proper recruitment and hiring of staff. A business process reengineering should also come in handy to help reinvent in large scaled manufacturing organizations so as to win the hearts of customers.

So it is evident that by implementing TQM practices will definitely help the organizations to achieve the desired level of operational performance as per the relationship discussed in this study. Therefore, the large scaled manufacturing organizations in Sri Lanka will be able to increase the operational performance in their peak seasons by implementing TQM in order to face for the competitiveness in the market place.

\subsection{Implications for Practitioners}

Since the competitiveness of today's business environment is rapidly increasing than it has been in the past decades, the organizations should follow several methods to achieve competitive advantage. Achieving operational performance is essential for an organization in order to face for the competitiveness. Therefore, the study suggests that implementation of total quality management practices is a key to achieve operational performance in an organization.

With the increasing importance of quality management in this global competitive market place, performance and assessment have become 
a key research area in academia and in the industry. It is evident from the findings of this study, performance management in organizations that use total quality management practices are indispensable as it drives the organizations to achieve business goals. Therefore, this study empirically verifies that in this era of globalization, large scaled manufacturing firms with operational performance enjoy substantial competitive advantage.

\subsection{Implication for Researchers}

The study provides inferences made from an instrument that is valid and reliable for the current study's context for evaluating the impact of total quality management practices on operational performance.

Further, the study provides a research framework that identifies significant relationships between total quality management practices on operational performance. Although several previous studies discussed the impact of total quality management on organizational performance, only a limited number of researchers have been discussing the relationship between total quality management and operational performance.

Therefore, the instrument developed in the study captures the relationship between total quality management, operational performance. The new instrument shall provide better guideline for researchers in the total quality management area, and thus, can be considered as a strategic management too and at the same time as a quality management tool.

\section{References}

Ahmad, S. and Schroeder, R.G (2003). The impact of human resource management practices on operational performance: recognizing country and industry differences. Journal of operations Management, Vol.21 No 1, pp.19-43.

Alamri, A. M., Alharthi, A. M., Alharthi., D. K., Alhabashi, W. S., \& Hasan., S. H (2014). Organisation performance improvement using TQM. International Journal of Computer Applications, Vol.108 No 9,pp. 29 - 33. 
Al-Damen, R. A (2017). The impact of Total Quality Management on organizational performance: Case of Jordan Oil Petroleum Company. International Journal of Business and Social Science, Vol.8 No 1, pp. $192-202$.

Almansour, Y. M (2015). The impact of Total Quality Management components on firms' performance, International Journal of Management Sciences, Vol. 6 No 8, pp. 384-394.

Anyango, D., Wanjau, K. \& Mageto, J. N (2012). Assessment of the relationship between quality management practices and performance of manufacturing firms in Nairobi. African Journal of Business and Management, Vol. 2, 2012

Arumugam, V., Ooi, K. B. \& Fong, T. C (2008). TQM practices and quality management performance- an investigation of their relationship using data from ISO: 2000 from Malaysia. The TQM magazine, Vol. 20 No. 6, pp. 636-650.

Barney, J (1991). Firm Resources and Sustained Competitive Advantage. Journal of Management, Vol. 17, pp.99-120

Bentler, P.M. \& Chou, C (1987). Practical issues in structural modeling, Sociological Methods and Research, Vol.16, pp.78117.

Boomsma, A \& Hoogland, JJ (2001). The robustness of LISREL modeling revisited. Structural equation models: present and future. A festschrift in honour of karl Joreskong, Vol.2 No.3, pp.139-168

Bou-Llusar, J.C., Ana B, E.T., Vicete, R.P. and Beltrain-Martin, I (2009). An empirical assessment of the EFQM excellence model: Evaluation as a TQM framework relative to the MBNQA Model. Journal of Operations Management, Vol.27, pp.1-22.

Chauke, S.S., Edoun, E. and Mbohwa, C. (2019). The effectiveness of total quality management and operations performance at a bakery firm in the city of Tshwane, South Africa. Proceedings of the International Conference on Industrial Engineering and Operations Management, pp. 2896-2907.

Curkovic, S., Melnyk, S., Calantone, R. and Handfeld, R (2000). Validating the Malcolm Baldrige National Quality Award 
Framework through structural equation modeling. International Journal Production Research, Vol.38 No 4, pp.765-791.

Deming, W.E. (1991). Foreword, in: W. W. Scherken bach, Deming's Road to Continual Improvement. (Knoxville, Tennessee), pp. vii \pm ix

Falkenreck, C. (2010). Reputation Transfer to Enter New B-to-B Market: Measuring and Modelling Approaches. New York: Springer.

Flynn, B.B., Schroeder, R.G. and Sakakibara, S (1995). The impact of quality management practices on performance and competitive advantage. Decision sciences, Vol. 26 No. 5, pp.659-691.

Forker, L. B. (1997). Factors affecting supplier quality performance. Journal of Operations Management, Vol.15, pp.243-269.

Hair, JF, Black, WC, Babin, BJ \& Anderson, RE (2010). Multivariate data analysis: A global perspective, $7^{\text {th }}$ edn, London: Pearson

Ho, L.A. (2008). What affects organizational performance?. Industrial Management \& Data Systems.

Hoang, D., Igel, B. and Laosiri hongthong, T.(2006). The impact of total quality management on innovation: findings from a developing country. International Journal of Quality \& Reliability Management, Vol. 23, No. 9, pp. 1092-1117

Hussain, T., Akhtar, N.A. and Butt, N.S (2009). Quality management: A case from Pakistan cotton yarn industry. Journal of Quality and Technology Management, Vol. 5 No.1, pp. 1-23.

Hutcheson, G. and Sofroniou, N. (1999). The Multivariate Social Scientist: Introductory Statistics Using Generalized Linear Models", Sage Publication, Thousand Oaks, CA.

Jaafreh, A.B. and Al-abedallat, A. Z. (2013). The effect of quality management practices on organizational performance in Jordan: An empirical study. International Journal of Financial Research, Vol. 4 No.1, pp.93-109.

Jerome, N. (2013). Impact of sustainable human resource management and organizational performance. International Journal of Asian Social Sciences, Vol.3 No.6, pp.1287-1292. 
Kaiser, H.F. and Rice, J. (1974). Little Jiffy, Mark Iv. Educational and Psychological Measurement, Vol. 34, pp.111-117.

Khanna, H. K., Sharma, D. D., \& Laroiya, S. C. (2011). Identifying and ranking critical success factors for implementation of total quality management in the Indian manufacturing industry using TOPSIS. Asian Journal on Quality

Kline, R.B. (2011). Principles and practice of structural equation modeling, $3^{\text {rd }}$ edn, The Guilford press

Kuo, T., Chang, T., Hung, K. and Lin, M (2009). Employees' perspective on the effectiveness of ISO 9000 certification: A Total Quality Management framework. Total Quality Management \& Business Excellence, Vol.20 No.12, pp.13211335.

Kuruppuarachchi. D. and Perera, H.S.C. (2010). Impact of TQM and Technology Management on Operational performance. The IUP Journal of operations management, Vol. 9, No.3,pp 2347.

Lai, K.H., \& Cheng, T.C.E. (2005). Effects of quality management and marketing on organizational performance. Journal of Business Research, Vol. 58 No.4, pp. 446-456.

MacCallum,RC, Widaman, KF, Zhang, S \& Hong, S. (1999). Sample size infactor analysis. psychological methods, vol.4,No.1, p.84

Malcolm Baldrige National Award Criteria (1995). United States Department of Commerce, National Institute of Standards and Technology, Washington, DC.

Malhotra, NK. \& Peterson, M (2006). Basic marketing research, International edition. Management, Vol.27, pp.495-511.

Mark, N. S., Philip, L., \& Adrian, T. (2009). Research Methods for Business Students. 5th Edition. England: Printise Hall.

Martínez-Costa, M. and Martínez-Lorente, A. (2008). Does quality management foster or hinder innovation? An empirical study of Spanish companies. Total Quality Management \& Business Excellence, Vol.19 No.3, pp.209-221.

Mehmood, S., Qadeer, F. and Ahmad, A. (2014). Relationship between TQM Dimensions and Organizational Performance, 
Pakistan Journal of Commerce and Social Sciences, Vol.8 No.3, pp. 662-679.

Neely, A.D. (2009). Exploring the Financial Consequences of the Servitization of Manufacturing, Operations Management Research, Vol. 2 No 1, pp. 103-118.

Ngambi, M.T. and Nkemkiafu, A.G. (2015). The impact of total quality management on firm's organizational performance. American Journal of Management, Vol.15 No. 4, pp.69.

Nunnally, JC \& Bernstein, IH (1994). psychometric theory, McGrawHill, New York: McGraw-Hill publishers

OECD. (2020). Entrepreneurship - Enterprises By Business Size OECD Data. [online]Availableat:<https://data.oecd.org/entrepreneur/enterpr ises-bybusinesssize.htm\#: :text=In\%20small\%20and\%20medium\%2 Dsized,employ\%20250\%20or\%20more\%20people.>[Accesse d 14 November 2020].

Powell, T.C. (1995). Total Quality Management as Competitive Advantage: A Review and Empirical Study. Strategic Management Journal, Vol.16, pp.15-37. http://dx.doi.org/10.1002/smj.4250160105

Prajogo, D. and Hong, S. (2008). The effect of TQM on performance in R\&D environments: a perspective from South Korean firms. Technovation, Vol. 28, No. 12, pp. 855-863.

Sadikoglu, E., \& Olcay, H. (2014). The effects of total quality management practices on performance and the reasons of and the barriers to TQM practices in Turkey. Advances in Decision Sciences, pp.1-17.

Samson, D. and Terziovski, M. (1999). The relationship between total quality management practices and operational performance. Journal of Operations Management, Vol.17 No 14, pp.393-409.

Sarkees, M. and Hulland, J. (2009). Innovation and efficiency: It is possible to have it all. Business Horizons, Vol. 52 No.1, pp.4555 . 
Saunders, M., Lewis, P., \& Thornhill, A. (2007). Research Methods for Business Students. (6th Ed.) London: Pearson.

Schumacker, RE, \& Lomax, RG (2010). A beginer's guide to structural equation modeling. $3^{\text {rd }} \mathrm{edn}$, Routledge academic

Sekaran, U. and Boggie. M. (2009). Research methods for business: A skill building approach, UK: John Wiley and sons.

Shapiro, S. and Wilk, M. (1965). An Analysis of Variance Test for Normality. (Complete Samples). Biometrika, Vol.52 (3/4), pp.591.

Sigei, C (2014). A total quality management and performance of multinational pharmaceutical firms in Nairobi, Kenya. A Research Project

Talib, F. (2013). An Overview of Total Quality Management: Understanding the fundamentals in Service Organization. International Journal of Advanced Quality Management

Terziovski, M. \& Samson, D. (1999). The link between total quality management practice and organizational performance. International Journal of Quality \& Reliability Management

Venkatraman, N. and Ramanujan, V (1986). Measurement of business performance in strategy research: a comparison of approaches. Academy of Management Review, Vol. 11, pp. 801-814

Walker, R., Dampour, F., Devece, C. (2009). management innovation and organizational performance: Mediating effect of performance management. 36 .

Winter, D. (1982). Material changes:Why and how they are made? Production, Vol.96, pp. 67-69.

Zahari, M. K., \& Zakuan, N (2016). The effects of total quality management on the employee performance in Malaysian manufacturing industry. Proceedings of Academics world 49th International Conference, Instanbul, Turkey. 